\title{
Maatalouden rakennekehitysnäkymät vuoteen 2013
}

\author{
Perttu Pyykkönen ${ }^{1}$ \\ Heikki Lehtonen ${ }^{2}$ \\ 1) Pellervon taloudellinen tutkimuslaitos PTT, Eerikinkatu28 A,00180 Helsinki, perttu.pyykkonen@ptt.fi \\ 2) Maatalouden taloudellinen tutkimuslaitos, Taloustutkimus (MTTL), Luutnantintie 13, 00410 Helsinki, \\ heikki.lehtonen@mtt.fi
}

\section{Tiivistelmä}

Tällä hetkellä maataloustukea saavia maatiloja on Suomessa noin 70000 kappaletta. Viimeisen kymmenen vuoden aikana tukea saavien tilojen määrä on vähentynyt noin 25000 tilalla eli yli neljänneksellä. Keskimäärin tämä on merkinnyt noin 3,5 prosentin vuotuista poistumaa. Tässä selvityksessä arvioidaan maatalouden toteutunutta ja tulevaa rakennekehitystä geometrisen trendin ja viljelijöiden demografisen analyysin avulla.

Vuosien 1995-2004 keskimääräisen vähenemisvauhdin (-3,6\% vuodessa) mukaan aktiivitilojen määrän voidaan arvioida vähenevän vuoden noin 72000 tilasta noin 53000 tilaan vuoteen 2013 (taulukko 4.1). Vuosien 1995-2003 kehityksen mukaan arvioituna vuoden 2013 tilamäärä olisi 50500 tilaa. Vuosina 1995-2003 alle 20 hehtaarin tilojen suhteellinen osuus on pienentynyt $56 \%$ :sta $43 \%$ :iin ja yli 50 hehtaarin tilojen osuus vastaavasti yli kaksinkertaistunut $7 \%$ :sta $17 \%$ :iin. Tilojen keskikoon kasvusta huolimatta tilarakenne painottuu edelleen suhteellisen pieniin tiloihin. Suuret, yli sadan hehtaarin tilat edustivat noin $3 \%$ tiloista vuonna 2003. Niiden osuus pinta-alasta oli sen sijaan yli $10 \%$ kokonaispeltoalasta. Keskimääräisen koon kasvaa trendin mukaan noin 44 hehtaariin tilaa kohden vuoteen 2013 mennessä

Kotieläintuotantotilojen vähenemisvauhti on ollut 6-7 \% vuositasolla, siipikarjataloudessa 9-10\%. Vuosina 1995-2004 kotieläintalouden päätuotantosuunnista väheni 24000 tilaa. Vuosina 1995-2004 viljatilojen lukumäärä väheni vain $0,1 \%$ vuodessa. Koska huomattava osa luopuvista kotieläintiloista jatkaa kasvinviljelyä, viljatilojen lukumäärässä ei tapahtune jatkossakaan suuria muutoksia.

Lypsykarjatiloja olisi geometrisen arvion mukaan runsaat 9000 vuonna 2013, vähennystä vuoteen 2004 siis noin 7 500. Arvion mukaan vähennys olisi CAP-reformin vuoksi kuitenkin vähän tätä nopeampi, kuitenkin korkeintaan 1000 tilaa nopeampi vuoteen 2013. Jos kuitenkin maidon hinta alenee merkittävästi, jopa $20 \%$ vuoden 2003 tasosta se aiheuttaa merkittävän lypsykarjatilojen vähenemisen suhteessa geometriseen arvioon pitkällä aikavälillä (vuoteen 2020).

Etelä- ja Länsi-Suomessa ei voida havaita pitkään toimineiden päätuotantosuuntana viljaa viljelevien tilojen luopuneen merkittävässä määrin tuotannosta. Kasvitilojen määrä alentunee jatkossa nopeasti Itä- ja Pohjois-Suomen alueilla joilla viljatilojen määrä on selvästi kasvanut viime vuosina.

Viljelijöiden keski-ikä kasvaa arvion mukaan 46,7:stä vuonna 2004 47,4:ään vuoteen vuonna 2013. Keski-iän nousu olisi suurempaa Itä- ja Pohjois-Suomessa kuin Etelä- ja Länsi-Suomessa. Ikärakenne muuttuisi kuitenkin jonkin verran. Sekä nuorimpien että vanhimpien viljelijöiden suhteellinen osuus kasvaisi verrattuna lähtötilanteeseen. Tämä johtuu siitä, että suurten ikäluokkien myötä myös jatkajien määrä kasvaa, kun jatkamisaktiivisuuden oletetaan säilyvän arviossa samana

Hintojen ja tukien alenemiset voivat jatkossa nopeuttaa tässä arvioitua maatalouden rakennekehitystä. Investointituen korkea hankekohtainen maksimitaso antaa mahdollisuuden Suomen mittakaavassa erittäin suuriin investointeihin ja nopeutuvaan rakennekehitykseen.

\section{Johdanto}

Maataloudessa on ollut meneillään voimakas rakennemuutos jo pitkään. Tilamäärä on vähentynyt yhtäjaksoisesti jo yli 40 vuotta. Enimmillään maatiloja oli 1960-luvun alussa sotien jälkeisen asutustoiminnan seurauksena yli 300000 . Tällä hetkellä tiloja on noin 70000 kappaletta. Viimeisen kymmenen vuoden aikana tukea saavien tilojen määrä on vähentynyt noin 25000 tilalla eli yli neljänneksellä. Keskimäärin tämä on merkinnyt noin 3,5 prosentin vuotuista poistumaa.

Maatalouden toimintaympäristö on muuttunut rajusti viimeisen kymmenen vuoden aikana, jolla on ollut selviä vaikutuksia myös rakennekehitykseen. Suurin muutos oli liittyminen EU:n jäseneksi, jolloin tuottajahintoja alennettiin rajusti ja tulojen alenemista korvattiin suorien tukien avulla. EU:n maatalouspolitiikkaa on uudistettu tuon jälkeen ja suora tuki on entistä enemmän pinta-alapainotteista. Tukien maksuperusteiden ja hintasuhteiden muutokset ovat vaikuttaneet pellonkäyttöön ja kotieläintuotantoon. Vilja-ala on kasvanut 
koko ajan, ja vastaavasti nurmiala on vähentynyt. EU-jäsenyyden myötä investointitukipolitiikka on suosinut aiempaa suurempia investointeja.

Tuotantopanosten hinnat ovat nousseet koko ajan viimeisen kymmenen vuoden aikana. Rakennekehityksen kannalta merkittävintä on ollut pellon hinnan nousu. Lisäpellosta entistä suurempi osa vuokrataan. Jo noin kolmannes peltoalasta on vuokrattua peltoa. Myös vuokrahinnat ovat nousseet, joskaan eivät aivan yhtä nopeasti kuin kauppahinnat. Merkittävä piirre viimeaikaisessa rakennekehityksessä on ollut tuotannon keskittyminen isoimmille tiloille ja tietyille maantieteellisille alueille. Kotieläintuotanto on kasvanut eniten siellä, missä se on ollut ennestäänkin vahvaa. Itä- ja Pohjois-Suomen osuus viljantuotannosta on kasvanut nautakarjatalouden rakennemuutoksen myötä.

Eri tekniikoiden ja tuotantomenetelmien kehitys on ollut voimakasta maatiloilla. Esimerkkeinä mainittakoon uudet tuotantotavat sikataloudessa kuten erilaiset ruokinta- ym. järjestelmät sekä tuotannon uudenlainen organisointi tilojen välisenä verkostona tai muuna yhteistyönä. Lypsykarjataloudessa on investoitu pihattonavetoihin lypsyasemiin ja automaattilypsyyn. Oma merkityksensä on ollut myös parsinavetoiden työtä säästävillä ratkaisuilla, koska osa investoinneista on ollut parsinavetoiden laajennuksia. Kasvintuotannossa kokonaisia työvaiheita on osalla tiloista voitu välttää suorakylvön avulla, joskaan se ei ole ollut kaikilla tiloilla ongelmatonta.

Toimintaympäristö muuttuu myös jatkossa. Koska maataloustukea irrotetaan tuotannosta, markkinat ohjaavat rakennekehitystä aiempaa enemmän. Vuonna 2003 sovittu CAP-uudistus alentaa maidon tuottajahintaa, mitä syventää edelleen EU:n vientitukien poistuminen, mikä alentaa myös viljan hintaa EU:ssa. Tällöin toisiaan seuraavat hyvät ja huonot satovuodet voivat johtaa varsinkin rehuviljan aiempaa suurempiin hintavaihteluihin EU:n sisämarkkinoilla. Jos lisäksi EU:n rajasuoja eli tullit tuonnille EU:n ulkopuolelta alenevat, se alentaa lihan hintoja EU:n sisämarkkinoilla. Elintarviketeollisuuden strategioilla ja niiden onnistumisella sekä neuvotteluvoiman kehityksellä vähittäiskauppaan nähden on suuri merkitys tuottajahinnoille ja yleensä hinnan merkitykselle kilpailukeinona. Koska eräissä EU-maissa, kuten Britanniassa, arvioidaan kriittisesti maatalousmenojen suurta osuutta EU:n budjetista, maataloudella on yhä enemmän tarvetta perustella tukien oikeutusta maatalouden tuottamilla julkishyödykkeillä. Jatkossa keskeisessä roolissa ovat toistaiseksi noususuunnassa ollut lihan ja maitotuotteiden kysyntä EU:ssa ja erityisesti Suomen lähialueilla, tuontilihan määrä ja hinta EU:n ulkopuolelta (lähivuosien WTO-ratkaisut), sekä tuotantosidonnaisen ja tuotannosta irrotetun maataloustuen määrä.

Seuraavassa tarkastellaan paitsi tilamäärän kehitystä, myös niiden tuotantosuunnittaisen ja tilakokoluokittaisen jakauman kehitystä vuoteen 2013. Samoin arvioidaan viljelijöiden ikärakenteen kehitystä ja rakennekehityksen alueittaisia eroja. Arviot tehdään sekä tilamäärissä tapahtuneen muutoksen perusteella että myel-vakuutettujen määrässä tapahtuneiden muutosten perusteella.

\section{Rakennearvioiden laskentaperusteet}

Aluksi tehdään geometrinen arvio, joka olettaa, että tilojen lukumäärän esim. viimeisen 10 vuoden aikana havaittu vähenemisnopeus säilyy ennallaan. Maatilojen lukumäärän muutokset ovat todellisuudessa vaihdelleet, mutta pitkillä yli 10 vuoden aikajaksoilla voidaan geometristen sarjojen todeta osuvan varsin hyvin havaittuun vähenemiskehitykseen. Geometristen sarjojen tehtävänä on näyttää selkeästi meneillään olevan kehityksen suuntaa ja voimakkuutta, ei ensisijaisesti toimia tilalukumäärän ennusteena, koska monet asiat saattavat varsinkin lyhyellä ja keskipitkällä aikavälillä (alle 5 vuotta ja 5-10 vuotta) selvästi poikkeuttaa kehitystä tasavauhtisista trendeistä.

Toiseksi tehdään demografinen arvio, jonka lähtökohtana ovat Melan tilastoista saadut tiedot vuosien 1995-2004 ikäluokittaisista (alle 30, 30-39, 40-49, 50-54, 55-59, yli 60) vakuutettujen määrästä ja alkaneiden vakuutusten määrä kaikissa Suomen kunnissa. Nämä laskelmat tehdään kunnittain.

Ensimmäisessä vaiheessa lasketaan edellisen vuoden tietojen perusteella vakuutettujen määrä seuraavana vuonna, jos kaikki jatkavat ja vain yläpäästä jäädään eläkkeelle. Lisäksi otetaan huomioon kussakin ikäluokassa olevien viljelijöiden vanheneminen ja jaetaan uudet vakuutetut tasan kahteen alimpaan ikäluokkaan. Toisessa vaiheessa lasketaan viljelijöiden muu luopuminen kuin em. yläpäästä eläkkeelle siirtyminen. Kolmanneksi lasketaan uusien vakuutettujen osuus edellisen vuoden yli 55-vuotiaiden määrästä. 


\section{Tilamäärän muutos}

Vuosien 1995-2004 keskimääräisen vähenemisvauhdin (-3,6\% vuodessa) mukaan aktiivitilojen määrän voidaan arvioida vähenevän vuoden noin 72000 tilasta noin 53000 tilaan vuoteen 2013 (taulukko 3.1). Vuosien 1995-2003 kehityksen mukaan arvioituna vuoden 2013 tilamäärä olisi 50500 tilaa. Vuonna 2004 tilalukumäärän väheneminen hidastui selvästi mikä vaikuttaa geometrisen sarjan tuottamaan ennusteeseen. On syytä tiedostaa geometristen sarjojen herkkyys lähtötietojen suhteen, lähtöaineistossa vuoden lisääminen tai poisjättäminen vaikuttaa ennusteeseen. Näin on varsinkin aluetasolla jossa monista eri tekijöistä johtuvat satunnais- ym. vaihtelut voivat vaikuttaa vielä enemmän tilalukumääräennusteeseen kuin koko maassa.

Taulukko 3.1. Tilalukumäärän muutokset maatalouden päätuotantosuunnissa 1995-2004 ja ennuste vuoteen 2013.

\begin{tabular}{|c|c|c|c|c|c|c|}
\hline & 1995 & 2000 & 2004 & $\begin{array}{l}\%- \\
\text { muutos } \\
1995- \\
2004\end{array}$ & $\begin{array}{l}\text { Ennuste } \\
2013\end{array}$ & $\begin{array}{l}\%- \\
\text { muutos } \\
2004- \\
2013\end{array}$ \\
\hline lypsykarjatilat & 32480 & 22913 & 17480 & $-46,2$ & 9418 & $-46,1$ \\
\hline muut nautatilat & 9394 & 5349 & 4768 & $-49,2$ & 2420 & $-49,2$ \\
\hline sikatilat & 6249 & 4316 & 3401 & $-45,6$ & 1851 & $-45,6$ \\
\hline siipikarjatilat & 2239 & 1231 & 1034 & $-53,8$ & 478 & $-53,8$ \\
\hline viljatilat & 29294 & 27510 & 28979 & $-1,1$ & 27722 & $-4,3$ \\
\hline muut tilat & 15906 & 16577 & 15862 & $-0,3$ & 11134 & $-29,8$ \\
\hline kaikki maatilat & 95562 & 77896 & 71524 & $-25,2$ & 53023 & $-25,9$ \\
\hline
\end{tabular}

Vuoden 2004 huomioidenkin näyttäisi edelleen siltä että kotieläintuotantotilojen vähenemisvauhti olisi 6-7 \% vuositasolla, siipikarjataloudessa 9-10 \%. Vuosina 1995-2004 kotieläintalouden päätuotantosuunnista väheni lähes 24000 tilaa. Koska huomattava osa luopuvista kotieläintiloista jatkaa kasvinviljelyä, viljatilojen lukumäärässä ei tapahtune jatkossakaan suuria muutoksia. Vuosina 1995-2004 viljatilojen lukumäärä väheni vain $0,1 \%$ vuodessa. Tämä tarkoittaa toisaalta sitä, että suuri määrä viljatiloja lopetti tuotannon vuosina $1995-$ 2004.

Lypsykarjatiloja olisi geometrisen arvion mukaan runsaat 9000 vuonna 2013, vähennystä vuoteen 2004 siis noin 7500 . MTT / taloustutkimuksen arvion mukaan vähennys olisi CAP-reformin vuoksi kuitenkin vähän tätä nopeampi, kuitenkin korkeintaan 1000 tilaa nopeampi vuoteen 2013. Jos kuitenkin maidon hinta alenee merkittävästi, jopa $20 \%$ vuoden 2003 tasosta se aiheuttaa merkittävän lypsykarjatilojen vähenemisen suhteessa geometriseen arvioon pitkällä aikavälillä (vuoteen 2020).

Etelä- ja Länsi-Suomessa ei voida havaita pitkään toimineiden päätuotantosuuntana viljaa viljelevien tilojen luopuneen merkittävässä määrin tuotannosta. Oletettavasti kasvitilojen luopumisalttius on suurin niiden tilojen joukossa jotka ovat vastikään luopuneet kotieläintuotannosta ja joille ei ole löytynyt jatkajaa. Näin syntyneiden kasvitilojen määrä alentunee jatkossa nopeasti Itä- ja Pohjois-Suomen alueilla joilla viljatilojen määrä on selvästi kasvanut viime vuosina. Tämä on todennäköistä, koska viljantuotannon kannattavuus on suhteellisen alhainen näillä alueilla ja kannattavuuden parantaminen tilaa laajentamalla on vaikeaa hajanaisten peltokuvioiden ym. syiden vuoksi.

Demografinen arvio johtaa likimain samaan lopputulokseen kuin edellä tehty geometrinen arvio. Demografista arviota tehtäessä joudutaan kuitenkin tekemään useita lisäoletuksia, joten se on herkkä paitsi perus- myös lisäoletuksissa tapahtuville muutoksille. Puhdas demografinen arvio antaa tiedon vain vakuutettujen määrästä. Jotta sen perusteella päästään tilamäärän arvioon, täytyy ottaa huomioon vakuutettujen määrässä tilaa kohden tapahtunut muutos. Tämä huomioiden tässä arviossa tilamäärä vähenisi hieman vajaaseen 50000 tilaan vuoteen 2013 mennessä. Arvio päätyy siten likimain samaan tulokseen kuin edellä geometrisessa arviossa. Rakennekehityksessä on kuitenkin selviä alueellisia eroja. Tehdyn arvion perusteella nähdään selvästi, että tilojen määrän väheneminen on nopeampaa Itä- ja Pohjois-Suomessa. Myös alueellisesta kehityksestä geometrinen ja demografinen arvio antavat hyvin yhteneväisen kuvan (kuvio 3.1). 


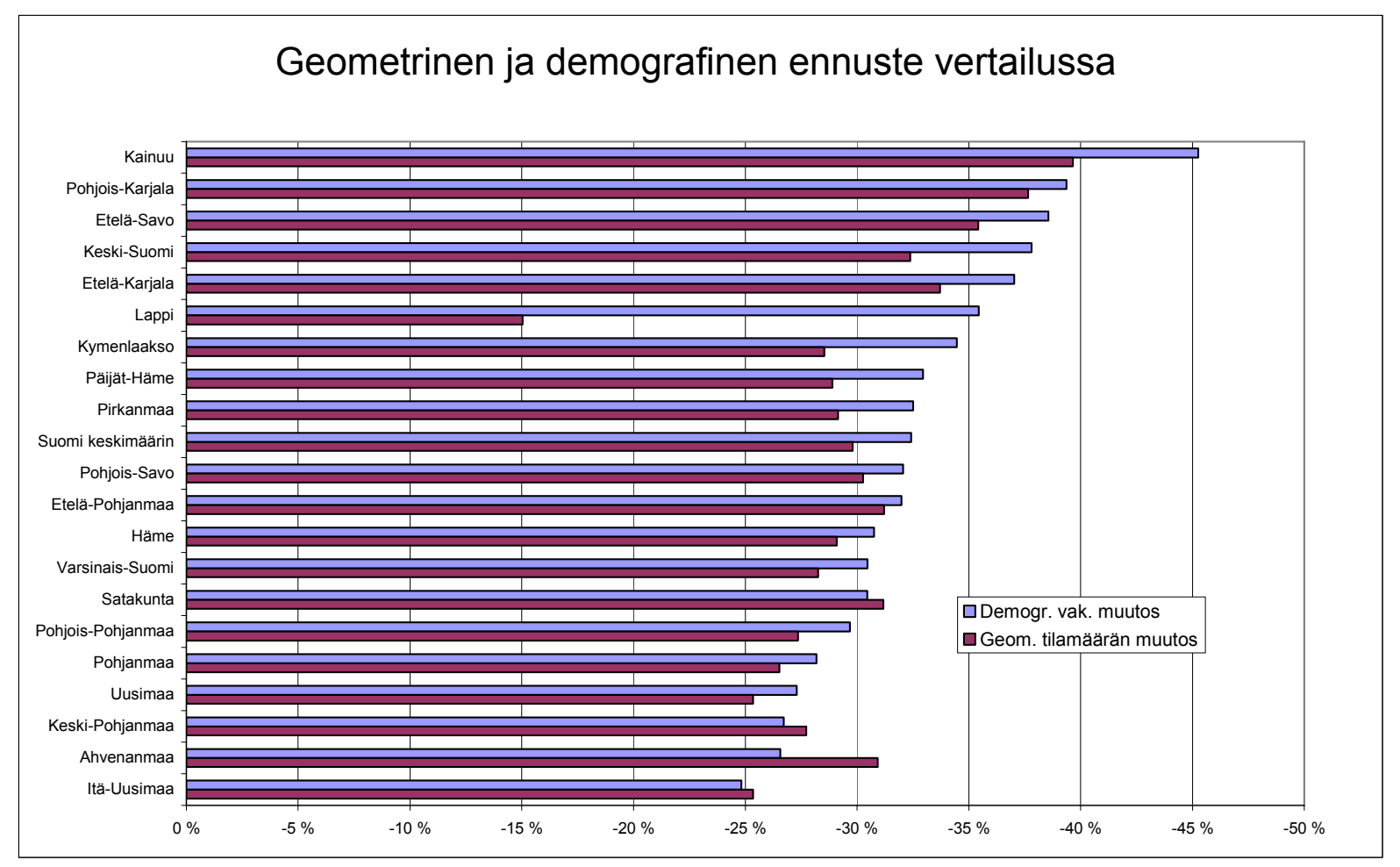

Kuvio 3.1. Demografisen ja geometrisen arvion vertailu.

Geometrisessa arviossa Itä-Uusimaa ja Uusimaa on käsitelty yhdessä päinvastoin kuin demografisessa arviossa, mutta kuviota varten ne on jaettu. Oikeastaan vain Lapin arviot poikkeavat merkittävästi toisistaan. Se johtunee siitä, että geometrisen arvion pohjana olevissa tilastoissa vuonna 1997 Lapin tilojen määrä lisääntyi, koska petovahinkokorvausten takia paljon porotiloja tuli mukaan tilastoon.

Vuosina 1995-2004 tukea saaneiden tilojen keskikoko on kasvanut $38 \%: 11$ a 22,8 peltohehtaarista 31,5 hehtaariin. Keskikoon vuotuinen kasvu on vaihdellut runsaasta puolesta hehtaarista puoleentoista hehtaarin. Tilojen keskikoko kasvaa sekä pienimpien tilojen määrän vähenemisen että suurimpien tilojen lisääntymisen seurauksena (taulukko 3.2). 
Taulukko 3.2. Peltoalan (ha) kehitys maaseutukeskuksittain 1995-2003 ja ennuste tilakoon kasvusta vuoteen 2013.

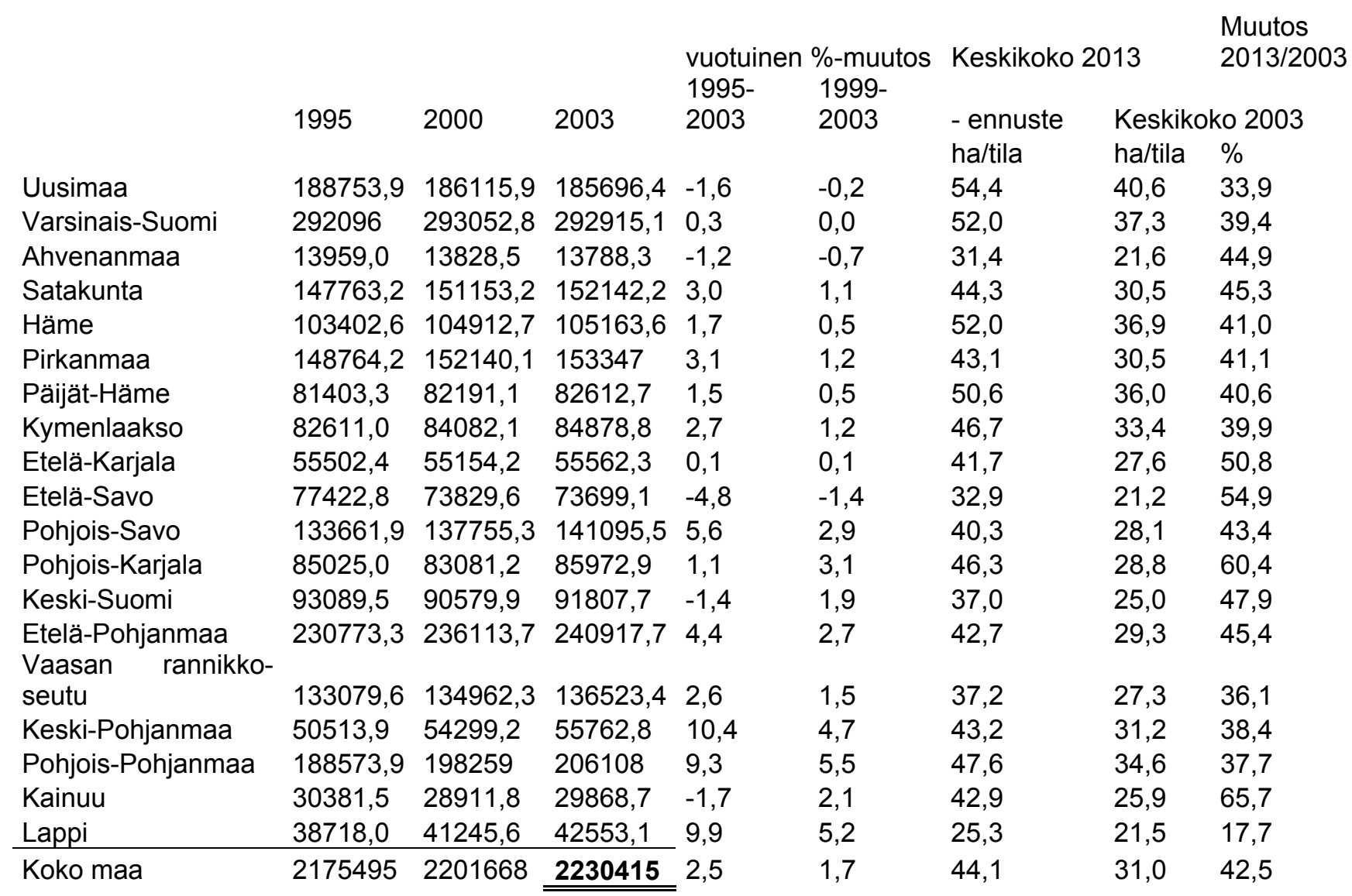

Vuosina 1995-2003 alle 20 hehtaarin tilojen suhteellinen osuus on pienentynyt $56 \%$ :sta $43 \%$ :iin ja yli 50 hehtaarin tilojen osuus vastaavasti yli kaksinkertaistunut $7 \%$ :sta $17 \%$ :iin. Tilojen keskikoon kasvusta huolimatta tilarakenne painottuu edelleen suhteellisen pieniin tiloihin. Suuret, yli sadan hehtaarin tilat edustivat noin $3 \%$ tiloista vuonna 2003. Niiden osuus pinta-alasta oli sen sijaan yli $10 \%$ kokonaispeltoalasta. Keskimääräisen koon kasvaa trendin mukaan noin 44 hehtaariin tilaa kohden vuoteen 2013 mennessä.

Suurten tuotantoyksiköiden osuus tuotannosta on kasvanut merkittävästi myös kotieläintaloudessa jossa tilakoon suurentamisen ansiosta saatavat mittakaavaedut ovat kasvintuotantoa selvemmät (kasvintuotanto kärsii suhteellisesti enemmän esim. huonon tilusrakenteen aiheuttamista haitoista).

Tuotannon keskittäminen suuriin tuotantoyksiköihin näyttäisi olevan myös jalostavan teollisuuden edun mukaista, koska tällöin voidaan säästää raaka-aineiden keräilykustannuksissa.

Mikäli vuosien 1995-2004 trendi tilalukumäärissä jatkuu ja tuotantomäärät eivät oleellisesti muutu, keskimääräinen tilakoko kasvaa sikataloudessa 80\% 2004-2013. Samoin maitotilojen keskikoko (lehmää per tila) kasvaa trendin mukaan $80 \%$ 2004-2013. Vastaavasti nautatilojen keskikoko kasvaa noin $90 \%$ ja siipikarjatilojen yli $100 \%$. Sen sijaan maitotiloilla tuotettu määrä kasvaa $85 \%$ tilaa kohden vähemmälläkin tilakoon kasvulla lehmien keskituotosten kasvun ansiosta. Jos keskituotos kasvaa 2\% vuodessa (eli vähän hitaammin kuin 1995-2004 keskimäärin), tilakohtaisen maitomäärän kasvu 80\%:1la edellyttäisi vain 50\% kasvua keskimääräisessä tilakoossa. Lypsykarjatilojen keskikoon kasvu olisi tällöin vain 46\%, vaihteluväli Etelä-Savon (jossa keskikoko vain 15 lehmää v. 2004) 22 lehmästä Pohjanmaan 31 lehmään vuonna 2013. Todennäköistä kuitenkin on, että maitotilojen keskikoon kasvu on lähempänä 80\%:a kuin 46\% koska maitolitrasta saatava tuotto alenee maidon hinnan alenemisen vuoksi.

Viljelijöiden keski-ikä kasvaisi 46,7:stä vuonna 2004 47,4:ään vuonna 2013. Keski-iän nousu olisi suurempaa Itä- ja Pohjois-Suomessa kuin Etelä- ja Länsi-Suomessa. Ikärakenne muuttuisi kuitenkin jonkin verran. Sekä nuorimpien että vanhimpien viljelijöiden suhteellinen osuus kasvaisi verrattuna lähtötilanteeseen. Tämä johtuu siitä, että suurten ikäluokkien myötä myös jatkajien määrä kasvaa, kun jatkamisaktiivisuuden oletetaan säilyvän arviossa samana. Ikärakenteet ilmenevät kuviosta 3.2. 


\section{Myel-vakuutettujen ikärakenne vuonna 2004 ja arvio vuodelle 2013}

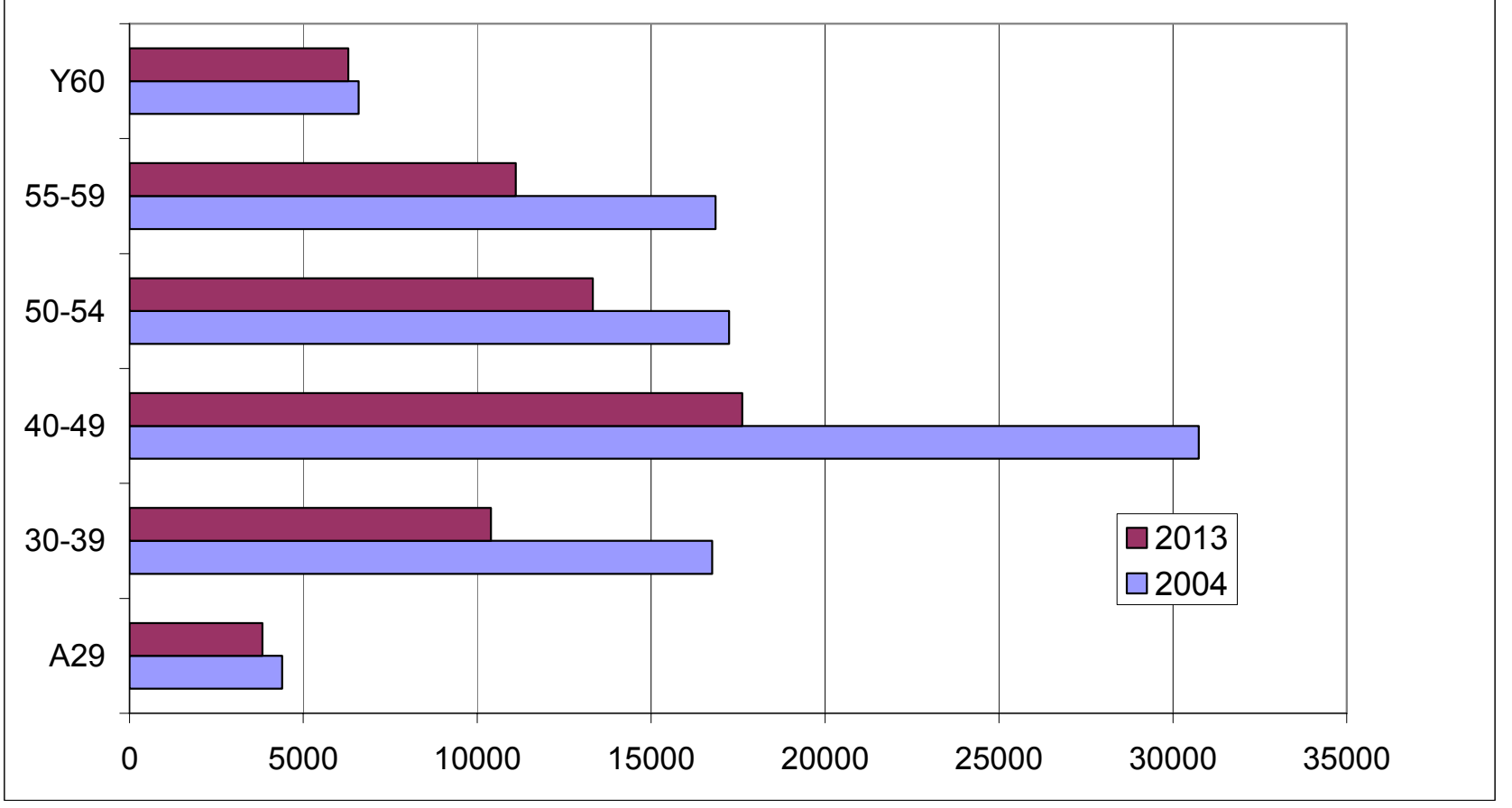

Kuvio 3.2. Viljelijöiden ikärakenteen muutos vuoteen 2013.

\section{Pohdintoja vaihtoehtoisista kehityssuunnista}

Viljatilojen määrä on säilynyt likimain ennallaan v. 1995-2004. Tämä tarkoittaa sitä, että lähes lopettaneita kotieläintiloja vastaava määrä viljatiloja on lopettanut tuotannon. Jos tulevaisuudessa sekä kotieläin- että viljatilojen lopettamisalttius säilyy ennallaan ja suuri osa kotieläintiloista siirtyy kasvitiloiksi, se merkitsee sitä, että kotieläintiloja on pian selvästi vähemmän kuin kasvitiloja. Luopuvia kotieläintiloja on lukumääräisesti yhä vähemmän ja lukumääräisesti yhä vähemmän tiloja siirtyy kasvitiloiksi. Tästä seuraa, että myös viljatilojen lukumäärä alkaa vähentyä. Näin käy varsinkin alueilla joilla kotieläintalous on vähentynyt merkittävästi ja kasvitilojen määrä vastaavasti noussut viime vuosina. Jos kasvinviljely ei ole sinällään kannattava sivuelinkeino, se tulee vähenemään etenkin alueilla jotka eivät tarjoa kasvinviljelylle hyviä luonnonolosuhteita. Tällä perusteella näyttää siis siltä, että Itä- ja Pohjois-Suomen alueilla tilamäärän väheneminen nopeutuu ja alenee pitkällä aikavälillä (yli 10 vuotta) nopeammin kuin maassa keskimäärin. Kun CAPuudistuksessa irrotetaan tukea tuotannosta se voi lisätä kesannointia erityisesti huonosti kannattavilla viljatiloilla.

Luopumisalttiuden ja jatkamisaktiivisuuden arviointia vaikeuttaa epävarmuus muun kansantalouden ja työllisyyden kehityksestä, varsinkin aluetasolla. Pellon pitäminen viljelyksessä joko viljelemällä viljaa tai kesannoimalla voi olla yksi tärkeä tulonlähde harvaanasutulla maaseudulla. Tuen irrottaminen tuotannosta antaa toisaalta mahdollisuuden varsinkin nuorille yrittäjille arvokkaan mahdollisuuden keskittyä päätoimeentulon hankkimiseen maatalouden ulkopuolelta silti maataloustuloa kokonaan menettämättä. Tästä näkökulmasta tuen irrottaminen voi olla maaseutualueille positiivinen asia, vaikka peltoa jäisikin aiempaa enemmän kesannolle.

Kun maitojauheen ja voin interventiohintoja alennetaan, maidon tuottajahinnan aleneminen riippuu kysynnästä EU:n sisämarkkinoilla sekä maitosektorin kilpailuasetelmasta. Näin ollen myös maitosektorin rakennekehitys EU:ssa ja Suomessa riippuu kysynnästä ja eri osapuolien markkinavoimasta. EU:n vientitukien poistuminen on erittäin todennäköistä seuraavan 5-10 vuoden sisällä ja se tekee ylijäämävoin viennin Venäjälle ja muualle EU:n ulkopuolelle selvästi tappiolliseksi. Markkinanäkymät näyttävät siis hyvästä kysyntätilanteesta huolimatta olevan haasteelliset. Vastaavasti lihamarkkinoilla hintakehitys on ollut viimeisen 1-2 vuoden aikana nouseva naudan- ja sianlihassa CAP-reformin ja vahvan kysynnän vuoksi. Toisaalta kasvava 
siipikarjan- ja naudanlihan tuonti EU:n ulkopuolelta ja kaupan vahva neuvotteluasema aiheuttavat paineita lihan tuottajahintoihin.

Tuotteiden hintakehityksellä voi olla merkittävä vaikutus luopumis- ja jatkamispäätöksiin (Pietola, Väre \& Lansink 2003). Voimakas hinnanlasku voi nopeuttaa aiottua luopumispäätöstä. Mikrotalousteorian pohjalta voidaan päätellä, että myös tuen irrottaminen tuotannosta voi vaikuttaa samalla tavoin, ts. aiottuja luopumispäätöksiä aikaistetaan ja korvausinvestointeja ei tehdä. Aloittavan yrittäjän kannalta hintakehityksellä on entistä suurempi vaikutus investointien toteuttamiseen, koska CAP-tukea on irrotettu tuotannosta ja hinnalla on entistä suurempi vaikutus investoinnin kannattavuuteen. Negatiiviset hintashokit voivat siis nopeuttaa tilalukumäärän vähenemistä. Lisäksi kansallisen pitkälti tuotantosidonnaisen tuen aleneminen voi nopeuttaa tilalukumäärän vähenemistä edellä esitettyihin trendiennusteisiin verrattuna vastaavalla tavalla kuin hintojen alennukset. Hintojen ja tukien alenemiset voivat vaikuttaa maatalouden rakennekehitykseen tuotannosta luopumisiin osin välittömästi tai muutaman vuoden viiveellä pienten tilojen käyttäessä pääomakantansa vähitellen loppuun ja pidättäytyessä investoinneista.

Jos hankekohtainen investointituki on jatkossakin korkea, se antaa mahdollisuuden Suomen mittakaavassa erittäin suuriin investointeihin ja nopeutuvaan rakennekehitykseen. Mikäli korkeita tukiprosentteja ja hankekohtaista kattoa sovelletaan käytännössä, se johtanee lyhyellä aikavälillä tuotantokapasiteetin ja tuotannon kasvuun. Tuotannon kasvulle olisi kotimarkkinoilla tilaa emolehmätuotannossa mutta hyvin vähän muissa tuotantosuunnissa.

Sektoreittain on syytä arvioida strategiatyössä sitä mille suhteellisille vahvuuksille suomalaisen tuotannon kilpailukyky kotimarkkinoilla ja viennissä rakennetaan ja kuinka vahvuudet ylläpidetään kilpailussa mm. uusien jäsenmaiden kanssa. Investointitukipanostuksia voidaan pohtia kansantalouden näkökulmasta, ts. kannattaako panostaa tuotannon laajennuksiin alenevien hintojen vientimarkkinoille, ja millaisia seurauksia nopealla rakennekehityksellä on maaseudulle maito-, nauta, sika- ja siipikarjasektorilla, ja onko irrotettu tuki ja kesantoalan lisääminen yhteiskunnallisesti hyväksytty tapa tukea erisyisesti syrjäisiä maaseutualueita. 